\title{
Electrical Equipment and Electronic and their Impact of Waste in the Republic of Kosovo
}

\author{
Prof.Ass.Dr. Naim Baftiu \\ Public University of Prizren " Ukshin Hoti " \\ Prizren Faculty of Computer Science The Republic of Kosovo
}

Doi:10.5901/ajis.2015.v4n1s2p95

Abstract

Managing waste electrical and electronic equipment is a challenge both for Kosovo and for all developed countries in the world bugs. Waste electrical and electronic equipment (MPEE), or ' e-waste', are a growing challenge for governments around the world. It is clear that we must change the way that designed, manufactured, used and managed electronic equipment after their exit from use, if we wish to continue to harvest the benefits that brings technological development, while at the same time not hurt people and the planet. In some states have not yet defined legal instruments, and also continue to see how e-waste going from rich countries, which have the capacity to handle it safely and appropriately. Kosovo so far no special legal regulation which would be included this type of waste, but as part of the process for adoption of EU legislation, the Ministry of Planning should prepare the Law on Waste Management of electrical and electronic equipment. While consumption of computers and electronic equipment is growing slowly in all parts of the world, it is not in balance with the associated increase in infrastructure for safe management of such waste electrical and electronic equipment. There are some problems that are caused by the use of increasingly large electronic devices and which pose a risk to human health, and also represent the ecological disaster. In Kosovo have different types of electrical and electronic waste such in this paper will be presented some data which will show how to manage respectively handle e- waste electrical and electronic equipment such.

Keywords: electrical and electronic equipment, waste management and ecology

\section{Introduction}

$\mathrm{E}$-waste is a generic term, used to describe electronic equipment old, obsolete or disposed, which contains electrical components. This includes a large part of the waste electrical and electronic equipment, and not just those related to the electrical grid, but also working with battery products, gain energy from wind or solar power other. These include many items, ranging from household white goods such as refrigerators and tester, up devices such as laptops and smart phones, extensive use items such as televisions and MP3 PlayerNet, to tools such as borer electric and sewing machines.

Waste electrical and electronic equipment (MPEE), or ' e-waste ', are a growing challenge for governments around the world. Environment Programmed United Nations estimates that some 50 million tons of e-waste generated each year around the world. Given current trends in the design and manufacture of electronic devices, which give impetus to more frequent cycles of replacement of these waste generation will not be reduced for a certain time. It is clear that we must change the way that designed, manufactured, used and managed electronic equipment after their exit from use, if we wish to continue to harvest the benefits that brings technological development, while at the same time not hurt people and the planet.

In this regard, steps have been taken in terms of policies, such as the European Union's Directive MPEE (WEEE Directive), which regulates the regime of e-waste management, with emphasis on the responsibility of producers to cover management costs after the obsolescence of electronic products. However, some states have not yet defined legal instruments, and also continue to see how e-waste going from rich countries, which have the capacity to handle it safely and appropriately, in some countries, do not have to fix this issue. Kosovo so far no special legal regulation which would be included this type of waste, but as part of the process for adoption of EU legislation, Ministry of Environment and Spatial Planning Law must be prepared to manage electrical and electronic waste electrical and electronic equipment in Kosovo. The document should be prepared starting point for all that should follow after the Law on management of electrical and electronic equipment and waste electrical and electronic equipment, as well as the obligations and challenges that will be its result. Qualitative research method is used where the first hand sources, such as interviews and legal documents, as well as secondary sources such as analysis of the perception of citizens of the Republic of Kosovo for e- waste and e - waste quantities in households 


\section{Electronic Equipment Modern Short Path towards Seniority}

Electronic devices have special features that manufacture and their use make influential source of ecological and social, and therefore they represent waste problematic and challenging. Some of the ways in which bad design and other practices make modern electronic devices obsolete very quickly and they are:

* Hardware problems - according to one report, $24 \%$ of laptops will break down in the first three years as a result of hardware problems.

* Software upgrades - New software can increase the volume of e - waste due to non-compatibility with older computers. For example, many computers do not have enough memory or processor speed to work with Windows Vested new.

* Shifts of the best phones - Companies often offer customers the best phones, for free or for very cheap price, encouraging frequent replacement of functional mobile phones.

In this regard, steps have been taken in terms of policies, such as the European Union's Directive MPEE (WEEE Directive), which regulates the regime of e-waste management, with emphasis on the responsibility of producers to cover management costs after the obsolescence of electronic products .

\subsection{The design of the evil and aggressive marketing by the companies that produce electrical and electronic equipment.}

Modern electronic devices quickly become obsolete and discarded. Innovations, such as mini - devices, resulting in equipment increasingly smaller and more functional, which are increasingly difficult to dismantle or to split into parts that are recyclable. In fact, many products are cheaper to replace than to fix, even if there who do it. Also, in addition to technological development, which renders obsolete equipment, as well as aggressive marketing of electronic companies doing that work equipment, to become obsolete after just one or two years of use. This results in rapid cycle's replacement artificially. When I would not want these devices are facing a big problem of waste that occurs in Kosovo.

\subsection{Electrical and electronic equipment contain many toxic substances.}

Over 1,000 materials used to produce our electronic devices and their components - semiconductor chips, circuits, drives (disk drives), and so on. Many of them are toxic, among which PVC, heavy metals (such as lead, mercury, arsenic and cadmium), Hexavalent Chromium, plastics and gases, which are harmful to human health if not properly managed. Disposal to landfill is one of the most common methods of e- waste disposal, despite the fact that due to the toxic contents of electronic devices, e-waste is very dangerous.

\subsection{Some of the risks to your screen television}

In your TV are toxic substances that can cause serious pollution, if your old TV sends to landfill. Old televisions with cathodes tube (CRT), containing from two to four kilograms of lead, which can release toxic chemicals when disposed in landfills, by contaminated groundwater.

New LCD TVs are starting to dominate the market, mercury containing lamps to illuminate their screen. Every LCD television uses only a few milligrams mercury. However , this metal is so toxic that even just one gram of mercury, and carried through the air each year to a lake of 80 meters, is enough to keep contaminated lake water at that level, the fish of the lake not be safe to eat.

EU accepted the toxic nature of the materials used in electronics and tries to respond to this situation through the Directive on the restriction of hazardous materials (DKMR), which bans and controlled use of certain materials in electronics, to all products sold in the European Union. If manufacturers would agree to make safer design with which to eliminate toxic materials, will be diminished risks after emerging from the use of our electronic devices.

Electronic devices contain precious materials and rare. Besides that contain many harmful and toxic substances, electronic devices also contain substances that are very valuable. Much of precious substances found in printed circuits board (printed circuit boards). The computers can be found iron, aluminum, copper, lead, nickel, tin, gold, silver, platinum and palladium. Metals and other precious materials exist in other electronic components, such as copper wire, aluminum and iron and household equipment. Quantities of 14 minerals that are used in modern electronics are critical level, while it is expected that the demand for these materials to triple by 2030.Many materials that are of great importance for the production of ICT equipment, are extremely rare, which makes them valuable. Rare materials, such as gallium indium 
and begin to play an important role due to their implementation of new technologies (for example, flat screens and touch screens, as well as photovoltaic solar energy). In addition, some of the materials used in electronics come very unreliable sources, places where crimes against humanity are made to extract them. With the disposal of old equipment in landfills or recycling no qualitative not use again materials that can be drawn from them despite the fact that some of them are really rare and due to criminality in society.

Even in Kosovo will deal with this very serious problem and the communities and environment in Kosovo would have been the victim of toxic and bad design and inadequate management e-waste. Reuse and recycling e-waste is difficult, because it contains components dangerous and unstable. A large number of electronic devices that do not need them anymore, end (illegally) in the landfill, the waste incineration ovens, along with other municipal waste, or removed in any other way inappropriate. Given the dangerous nature of certain materials in electrical and electronic equipment, mismanagement of e-waste means that people and the environment pay the price for toxic and bad design manufacturers.

Minimizing the impact of electronic devices and the real - technology spending wastes include social and environmental impacts throughout its life cycle. Current trends in production and consumption of electronic equipment, together with the lack of options for safe management of e- waste in many countries suggest that, as communities and the environment pay the price for toxic and inefficient design. The current situation in Kosovo is unfair and unsustainable simultaneously.

To prevent e-waste crisis and to protect the environment and human health in the chain of electronic products have all parties to take action.

Manufacturers should:

* To make cleaner products

* To make a more lasting products

* Let's take back their products for reuse and recycling safe

Government of Kosovo should:

* To prohibit the import and export of e - waste

* Prohibit dumping of e - waste in landfills - promote reuse of hardware and make it mandatory recycling e waste.

4 Bring law and producer responsibility to promote design.

* To supervise actors and punish offenses

Consumers should:

* Buy less, and buy ecologically.

* To return their goods back to the manufacturer for reuse and safe recycling.

Any approach to minimize the negative impact of electronics and e-waste, requires that manufacturers take primary responsibility for their products throughout the lifecycle. However, this does not mean that others should not play any role. For example, the government of the Republic of Kosovo should ensure the right policies and laws which will encourage design and ensure respect for the rights. Also, to minimize the negative impact of electronic equipment and waste is, should be treated the issue of skills for consumption and disposal of equipment by consumers, which means that customers have key roles.

Categories of products MPEE Directive are:

- Large household appliances

- Small household appliances

- Equipment for IT and telecommunications

- Equipment for entertainment electronics

- Equipment for lighting

- Electrical and electronic tools

- Games, facilities for leisure and sport

- Medical Apparatus

- Instruments for inspection

- The machines

For wastes that do not come from families, manufacturers have individual responsibility for MPEE new, but the old MPEE have responsibility only when offering new products during product exchange old with new. Other major obligations include access for users to information necessary for Antes how to avoid e-waste properly and manufacturers to mark their products and provide information for re-use and safe handling of their products. Also, countries have an 
obligation to do checks and monitoring the situation, to make appropriate implementation, including appropriate penalties for possible violations of law Directive.

\section{Limitation of Hazardous Substances}

The European Parliament adopted the Directive on the restriction of hazardous substances (DKMR) in 2003, but it entered into force in July 2006. DKMR considered as a supplement Directive MPEE, because the limited production phase, although there impact on products that are obsolete. It aims to restrict the use of certain hazardous substances in electrical and electronic equipment. In this way, the protection of human health and ecological assisted is restoration and waste removal. With this Directive, the Member States are required to adopt the national legal framework, which will limit the use of four heavy metals (lead, cadmium, mercury and chromium hexavalent) and two groups of refractory materials with bromine (GDP and PBDE) the production of new electronic devices (although there are exceptions for certain uses of these substances until replacements are found). The Directive has a global impact because it treats the products imported into the EU, not just those that are produced within its borders

\subsection{Products that use energy}

These products have intended to improve the environmental performance of products throughout their lifecycle, through systematic integration of environmental aspects into product design phase. As a framework directive, it has no direct provision for the necessary requirements for certain products, but only defines the conditions and criteria for determining the conditions for each product separately.

Products candidates for measures to be implemented are those that:

* Have a considerable impact on the environment.

4 Circulation in the EU.

* Clear potential and significant environmental improvements.

Measures for implementation may be different forms, including the necessary regulation, voluntary industry initiatives etc. Until now adopted a number of measures for implementation, including those for computers and monitors, TV sets, refrigerators and refrigeration appliances, and home lighting. In 2009 it was decided that ordinary bulbs are contrary to the Directive and started their gradual removal from use, in the context of the Directive.

\subsection{How would Kosovo faces e-waste management law for electrical and electronic equipment and waste electrical and electronic equipment.}

Kosovo with this law regulates the requirements for environmental protection that must meet legal and physical persons who produce and bring to market the Republic of Kosovo electrical and electronic equipment and who treat waste electrical and electronic equipment, and other entities that participate in the production and marketing of electrical and electronic equipment, limiting the use of certain hazardous substances in the manufacture of electrical and electronic equipment, method of collection, handling, processing and waste disposal electrical and electronic equipment, as well as other issues relating to the management of waste electrical equipment and electronics.

The goals of this draft law should have been:

* Reducing the negative impact of waste electrical and electronic equipment on the environment and human health at the lowest level possible;

* advancement of standards for environmental protection by producers, traders and end users throughout the life cycle of products, especially during the treatment, processing and disposal of waste electrical and electronic equipment;

* obstructing the creation and disposal of waste electrical and electronic equipment;

* achieve high levels of reuse, recycling and other types of waste processing electrical and electronic equipment, as well as reducing the disposal of waste electrical and electronic equipment in landfills;

* creating conditions for the establishment and development of the market for reuse, recycling and other types of processing waste electrical and electronic equipment, and

4 Ensuring equal position in the market for natural and legal persons domestic and foreign, as well as avoidance and removal of trade barriers that can distort the market of electrical and electronic equipment. 


\section{Analysis and Recommendations}

Proposal Preparation and Management Law electrical and electronic equipment and waste electrical and electronic equipment and its entry into parliamentary procedure mean a lot for Kosovo. Draft law should be harmonized with the European directives and the proposed text is clear aim of proposing to contribute to preserving the environment in the Republic of Kosovo

\subsection{Draft Law adaptation according to EU directives}

Draft law includes key needs for waste management of electrical and electronic, but, however, consider that in some articles must be some necessary changes, which will facilitate the interpretation and application of the law in the future.

\subsection{Goals of the collection.}

In the territory of the Republic of Kosovo, until December 31, 2020, must be collected at least 4 kilograms of household waste per capita per year. Revision of Directive 2002/96 / EC showed MPEE fixed targets such collection does not address the problem in the best way. A large part of the Member States has failed to meet its target, while for some other countries, it definitely was not a challenge. Therefore, the proposal for revision of the directive is that the collection targets to be a certain percentage of equipment put on the market, and that $65 \%$ of the average amount of electrical and electronic equipment put on the market during the past two years. Research shows that families, as well as companies, have large amounts of equipment to throw, so that this target can be met quickly.

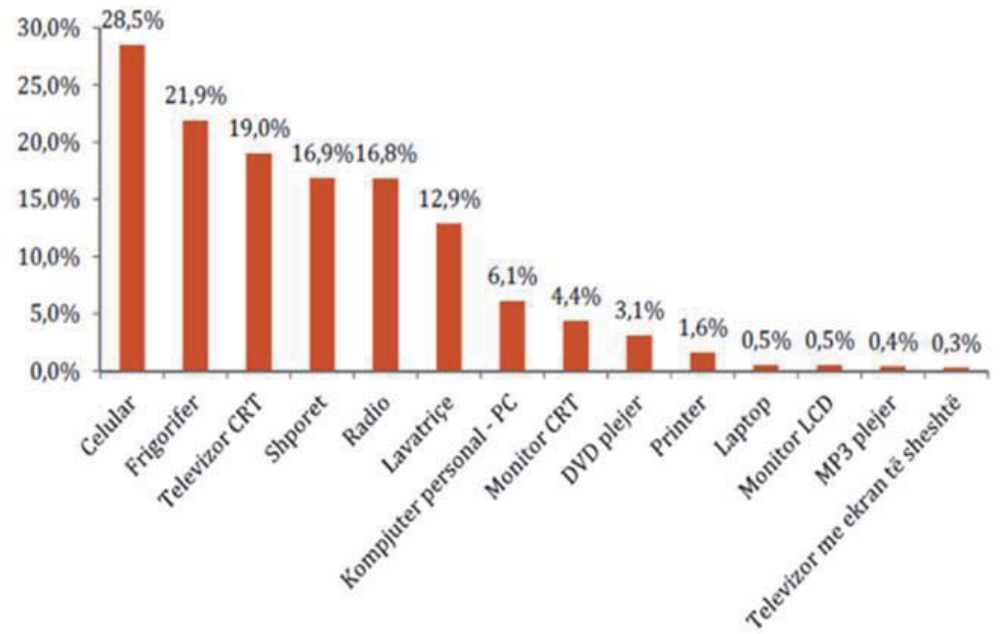

\subsection{Percentage of household not already used, but kept at home}

This graph shows the percentages of household not already used to being kept in the houses of Kosovo. These devices represent potential e-waste can be found soon cast along with other municipal waste. All these devices are stored in the house a long time and enabling their disposal, will probably reach the target set by law, but coming years could be coming to a reduction of the amount of e- waste collected.

\section{The Simple Way to Remove Household Waste}

Currently, the draft law envisages to have a collection center 30000 inhabitants and citizens have the opportunity to leave free waste electrical and electronic equipment from which traders buys new equipment.

Some data indicate that a citizen of prefer the system that is proposed by this law, but a part considers that there should be some solution / center to left as Gift waste electrical and electronic equipment, close to home them. 


\subsection{Activities of the Government of Kosovo}

Government can play an important role in policy development and regulation of habits, in order to promote good practices related to electronic equipment and e-waste. Therefore, the Kosovo government should implement the following recommendations:

Should not be allowed to e-waste:

$\$$ Get in - or out.

* The essentials are restrictions on import and export of e-waste, in order to protect communities and the environment in countries without safe infrastructure for e-waste.

* Waste exported represent lost valuable resource for the recycling industry in the country of import, while imported waste can overflow waste management systems of importing countries. Also, is-waste export suffocates innovation that is needed to address the problem from the beginning, during the design and production.

4 Do not let e-waste going to landfill.

* E-waste dumped in landfills, or in any other location, not only deadly, but it also presents an opportunity to release.

* Toxic materials in e-waste can contaminate soil, water and air, but when electronic devices are not reused or recycled, lost valuable resources. Instead, they should be handed legitimate waste operators.

* If that is functional, the device must be re-used, and if it is not functional, it must be recycled safely. Adopt a legal framework for responsibility of the manufacturer, design encouraged.

To enable electronic equipment manufacturers pass from toxic and inefficient design in that it is safe for people and the planet, the Kosovo government should:

* Planning to introduce a ban on substances that initially manufacturers to reduce, with no time even to eliminate toxic substances in electronics.

* Transfer the individual responsibility for managing the products after the obsolescence of their manufacturers.

* To implement ambitious goals for collection and retrieval, in order not to allow e-waste end up in landfills and motivate manufacturers to develop appropriate and effective infrastructure for collection, disassembly, reuse and recycling.

* To implement serious and applicable standards for treatment and processing.

Since an end to harmful practices for waste treatment (for example, dumping in landfills, burning in oven and exports), and to encourage continuous improvement of e- waste management, all operators of collecting and treatment waste must be licensed and have passed inspection by the relevant national agency for the environment.

\section{Conclusion}

Managing waste electrical and electronic equipment poses a challenge for developed countries. The adoption of the Law on electrical and electronic equipment and waste electrical and electronic equipment, Kosovo begins long war with the hazardous waste, which representing one of the most dangerous destroyers of the environment in modern society. Harmonization of Kosovo legislation with European legislation and the approach to the European Union is an additional motive for behavior and implementation of this law. Metamorphosis will continue to follow the law and implement activities that will assist in its implementation in Kosovo.

\section{References}

Rrjeti ballkanik për përfaqësim gjatë menaxhimit të e-mbeturinave: http://www.e-otpad.ks Ministria për mjedis jetësor dhe planifikim hapësinor: http://www.moepp.gov.ks/ Udhëzues për e-mbeturina: www.ewasteguide.info Zgjidhja e problemit me e-mbeturina - iniciativa StEP: http://www.step-initiative.org/ Portali i Komisionit Evropian për MPEE: http://ec.europa.eu/environment/waste/weee/index_en.htm 